\title{
Opportunities for Integrated Landscape Planning - the Broker, the Arena, the Tool
}

\author{
Julia Carlsson ${ }^{*}$, Gun Lidestav1, Therese Bjärstig, Johan Svensson, Eva-Maria Nordström1 \\ 1 Swedish University of Agricultural Sciences, Dep. of Forest Resource Management, Skogsmarksgränd, SE-90183 Umeå, Sweden \\ 2 Umeå University, Dep. of Political Science, SE-90187 Umeå, Sweden \\ 3 Swedish University of Agricultural Sciences, Dep. of Wildlife, Fish and Environmental Studies, Skogsmarksgränd, SE-90183 \\ Umeå, Sweden
}

\begin{abstract}
As an integrated social and ecological system, the forest landscape includes multiple values. The need for a landscape approach in land use planning is being increasingly advocated in research, policy and practice. This paper explores how institutional conditions in the forest policy and management sector can be developed to meet demands for a multifunctional landscape perspective. Departing from obstacles recognised in collaborative planning literature, we build an analytical framework which is operationalised in a Swedish context at municipal level. Our case illustrating this is Vilhelmina Model Forest, where actual barriers and opportunities for a multiple-value landscape approach are identified through 32 semi-structured interviews displaying stakeholders' views on forest values, ownership rights and willingness to consider multiple values, forest policy and management premises, and collaboration. As an opportunity to overcome the barriers, we suggest and discuss three key components by which an integrated landscape planning approach could be realized in forest management planning: the need for a landscape coordinator (broker), the need for a collaborative forum (arena), and the development of the existing forest management plan into an advanced multifunctional landscape plan (tool).
\end{abstract}

\section{Keywords:}

Collaborative planning, Forest management plan, Landscape approach, Sweden, Transdisciplinarity.

\footnotetext{
*Corresponding author. Email: Julia.Carlsson@slu.se
}

(C) The Authors. 2017. Landscape Online. This is an Open Access article distributed under the terms of the Creative Commons Attribution License (http://creativecommons.org/licenses/by/4.0), which permits unrestricted use, distribution, and reproduction in any medium, provided the original work is properly cited. 


\section{Introduction}

\subsection{The landscape concept}

The landscape as a concept and approach is evolving in research, policy and practise, in Sweden and elsewhere around the world. Landscapes are increasingly being understood as multifunctional and dynamic entities of social and ecological systems; that is, spatially and/or temporally defined entities where multiple functions and values associated with natural, cultural and societal values are integrated in the interests of both existing and potential land users (Angelstam et al. 2015; Bolliger et al. 2010; Brandt \& Vejre 2004; de Groot 2006; Gallent et al. 2004; Selman 2012; Termorshuizen \& Opdam 2009). Many critical landscape functions are affected by human interactions with natural processes (Termorshuizen \& Opdam 2009), such as climate change mitigation and adaptation, biodiversity, economic productivity, energy security, public health and wellbeing, social cohesion and aesthetic beauty (Bolliger et al. 2010; Brandt \& Vejre 2004). Consequently, policy-makers, scientists and practitioners have raised arguments for a landscape perspective in land-use planning and management where values, interests and needs are integrated. The development and ratification of the European Landscape Convention (Berlan-Darqué et al. 2008; Jones \& Stenseke 2011; Secco et al. 2014) is an example in this direction.

From a biophysical point of view, a landscape is a continuum ofland covertypes,(e.g. forest, agricultural land and water bodies) and the transitions between them (Svensson et al. 2012). Spatial and temporal perspectives on multiple scales are especially important under changing premises caused by climate change, new land use policies or changing demands on natural resources since adaptation, mitigation and sustainability opportunities rely on holistic approaches (cf. Svensson et al. 2012). Since the values of the forest landscape are interrelated and interacting, it is logical to promote coherent and comprehensive planning to secure and benefit the provision of multiple values for multiple purposes and objectives. However, it can be challenging to apply a landscape approach in practical land-use planning, since a landscape is an entity whose geographic scale depends on what type of land use that are in focus in a planning process (Bettinger et al. 2009; Jørgensen et al. 2016). Furthermore, when several components (e.g. habitats) and demands on landscapes are considered simultaneously, land use conflicts may occur (Bolliger et al. 2010; Monroe \& Butler 2015). Since planning processes are dependent on social structures of institutions and systems (Roe 2007), a feasible integrated landscape planning (ILP) approach could provide an inter-sectoral framework by functioning as an "umbrella" that connects demands and planning tools from different sectors (Brandt \& Vejre 2004; Carvalho-Ribeiro et al. 2010; Cullotta et al. 2015; Dolman et al. 2001; MacFarlane 2007). It has been clearly expressed at high political levels - e.g., the key policy messages adopted by FAO for achieving the sustainable development goals that improved coordination (key message no. 5) and integrated land-use planning (key message no. 8) are critical planning aspects that need to be developed (FAO 2016).

\subsection{Effects of a sectorial planning tradition}

The European Landscape Convention stresses the importance of enhancing awareness and knowledge exchange on landscapes as socio-ecological systems (Mikusinski et al. 2013). However, in Sweden, as in many other countries, the sectorial responsibilityframe is deeply rooted in the system of public administration. This has resulted in a planning paradigm where the regulatory authorities act independently of each other (Andersson et al. 2013; Beland Lindahl et al. 2017; Hysing 2009) and thus where the multifunctional components that characterises, e.g., rural planning (Gallent et al. 2004), are reduced or absent. Consequently, forestry, agriculture, infrastructure, nature conservation, energy production and reindeer husbandry sectors, which are dominant in northern Sweden, are planned separately without integration (Esselin 2014; Sandström \& Lindkvist 2009). The sectorial planning paradigm in the Swedish forest sector has prevailed throughout the industrialisation era of the 20th century and resulted in a situation where a monofunctional land use strategy has been adopted as the most economically efficient (Brandt \& Vejre 2004). 
"Sector responsibility" was formally introduced in the forest sector in 1988 and further strengthened as the biodiversity strategy was adopted in the early 1990s (Beland Lindahl et al. 2017; Bush 2010). Different authorities are responsible for various, often overlapping, components and functions of a landscape, and have unclear roles and mandates considering the landscape as a whole. This is particularly obvious on national and regional levels, in contrast to local level where municipality agencies are expected to exercise holistic considerations in their comprehensive plans (Andersson et al. 2013; Bjärstig et al. 2017). Furthermore, there is often an incoherency in how various sector policies interpret the concept of 'landscape' (Esselin 2014). Even though sectors such as forestry, agriculture or water management are increasingly including sustainable development objectives in planning, their separate spatial, policy and strategic foci hinders sustainable landscape management (cf. Svensson et al. 2012) across biophysical and jurisdictional borders (Farcy 2004).

The large number of private non-industrial forest (NIPF) owners ${ }^{1}$ in Sweden is a contributing factor (Andersson et al. 2013; Angelstam et al. 2015; Forsberg 2012) to the sectorial "isolation" in the forestry sector. Although diversity in objectives and behaviour may be expected (cf. Simonsson et al. 2015), the NIPF owners commonly engage consultancy services and contractors for the forestry operations, which leads to streamlining of forest management implementation (Hokajärvi et al. 2009; Hujala et al. 2009; Kindstrand et al. 2008). Consequently, the magnitude and diversity of NIPF ownersare not reflected in a higher degree of diversification on estate and stand levels, due to dominant logic of the industrial forestry (Holmgren \& Arora-Jonsson 2015).

Multifunctionality can to some extent be dealt with by laws and regulations. For example, the current Swedish Forestry Act states that environmental and social functions are to be considered equally important as production functions (goals). It can be claimed that current forest management plans have a multifunctional approach, since measures such as

1 A total of 329541 persons, who own $50 \%$ of the productive forest land in Sweden (SFA 2014) nature conservation, water quality improvement (buffer zones), recreational interests and carbon sequestration are increasingly being considered (Beland Lindahl et al. 2017; Ingemarson 2004). However, with an apparent shift to more liberal forms of policy steering of the Swedish forestry sector during recent decades (Appelstrand 2012; Beland Lindahl et al. 2017; Simonsson et al. 2015), the implementation of equal importance to different functions and goals basically rests on voluntary measures by assigning forest owners "freedom with responsibility" in management decisions.

The past and present procedure of creating a forest management plan (FMP) for private owners has been thoroughly described by Brukas and Sallnäs (2012). The FMP works as a decision-support tool for the NIPF owner, but is also a policy instrument in which regulations, planning instructions and forest inventory methods are promoted by the Swedish Forest Agency as a management paradigm responding to the owner's concerns. Timber production is usually prioritised. The FMP is nonmandatory, and there is no data about how many Swedish NIPF owners that have a FMP.

\subsection{Collaborative processes - challenges and opportunities}

Collaborative processes in forest and landscape governance, management and planning are increasingly being promoted to bring together diverse actors in dialogue to address complex problems (Appelstrand 2002; Berlan-Darqué et al. 2008; Innes \& Booher 2010; Jones \& Stenseke 2011; Sandström 2015). It has been argued that "when local communities and other stakeholders are empowered through ongoing involvement in collaborative processes, participants can develop a sense of responsibility for the successful implementation of management plans and even govern their own actions to meet established goals"(Keough \& Blahna 2006, p. 1375). Collaborative planning has been defined as "an interactive process of consensus building and implementation using stakeholder and public involvement" (Margerum 2002, p. 237). The concept advocates the establishment of partnershipbased arenas as a way to reach mutually acceptable outcomes (Raitio 2012; Wondolleck \& Yaffee 2000). 
Although it can be argued that Swedish forest policy is based on a long tradition of consensus-oriented deliberations between stakeholders (Schlyter \& Stjernquist 2010), the range of actors who have formal rights or duties in the forest governance system is relatively narrow (Beland Lindahl et al. 2017). Andersson et al. (2013) argued that there are several problems regarding the implementation of collaborative approaches in Sweden. On the local scale, there are few examples of formal for a where different stakeholders can meet regularly to discuss issues regarding land-use, planning and management of multiple forest values, across areas with ownership diversity.

An interesting example of a landscape scale arena is the Model Forest concept. It was first developed in Canada and has resulted in the establishment of more than 50 Model Forests around the world (Bonnell et al. 2012; IMFN 2015). The Model Forests are voluntary initiatives linking forestry, research, agriculture, recreation, and many other land basegenerated activities within a given spatial entity (landscape) through an inclusive, collaborative and transparent stakeholder-driven organisational body. The economic, ecological and socio-cultural values and needs of local communities are combined for long-term sustainability on a landscape scale. The Model Forest concept focuses on communicative and collaborative approaches, mixing local, traditional, and scientific knowledge in a transdisciplinary multistakeholder and multi-functional manor (Bonnell et al. 2012; Ho et al. 2014). Other landscape initiatives, such as the UNESCO Man and the Biosphere Programme (Esselin 2014; Richnau et al. 2013) have approaches that in similar ways encompass bottomup perspectives, transparency and collaboration.

\subsection{Objectives}

Departing from a general assumption that successful implementation of integrated and multifunctional landscape planning is not realised due to institutional barriers, we take an explorative route (cf. Hahn \& Knoke 2010) to elucidate opportunities for advance. Weaddress three commonly recognised barriers in the literature: the need for participation, transparency and bottom-up input through knowledge-based facilitation; the need for a collaborative platform or forum where solutions may be tested, evaluated and communicated; and the need for a better planning framework by developing the traditional and wellknown FMP. Vilhelmina Model Forest, which was established as the first Model Forest in Europe in 2004 (Svensson et al. 2012), is used as an empirical testing ground.

\section{Methods and analytical framework}

\subsection{Vilhelmina Model Forest - the case}

The Vilhelmina Model Forest (VMF) encompass the land base of the municipality of Vilhelmina, in northwest Sweden. The landscape area, in total $850,000 \mathrm{ha}$, is dominated by boreal forest and the Fennoscandian mountains (Svensson et al. 2012); $40 \%$ is subject to forest management, $21 \%$ is protected forested area (mostly non-productive forest), and $38 \%$ is non-forested area (Figure 1). Forest ownership in the area encompasses a mix of state and industry (64\% of the productive forested land) and non-industrial private forest owners ( $36 \%$ of the productive forest land). According to demographic data from 2016, there are 2621 NIPF owners, where of 1177 are residents in the municipality, corresponding to $17 \%$ of the inhabitants in Vilhelmina (SFA 2016). Vilhelmina's population has decreased over the last few decades and currently numbers approximately 6800 inhabitants (Statistics Sweden 2016).

The diverse values provided by forests in the Swedish northern inland have been described by, for example, Sandström C. et al. (2011, 2016), Svensson et al. (2012), and Sténs et al. (2016). Historically, the municipality has been highly dependent on timber production. The last saw mill was shut down in 2013, which at the time was the largest private employer in Vilhelmina. Specific for northern Sweden, the indigenous Sami population has the reserved right to conduct the traditional livelihood of reindeer herding, which is taking place on the same land as forest production and other land use (Sandström P. et al. 2016). 


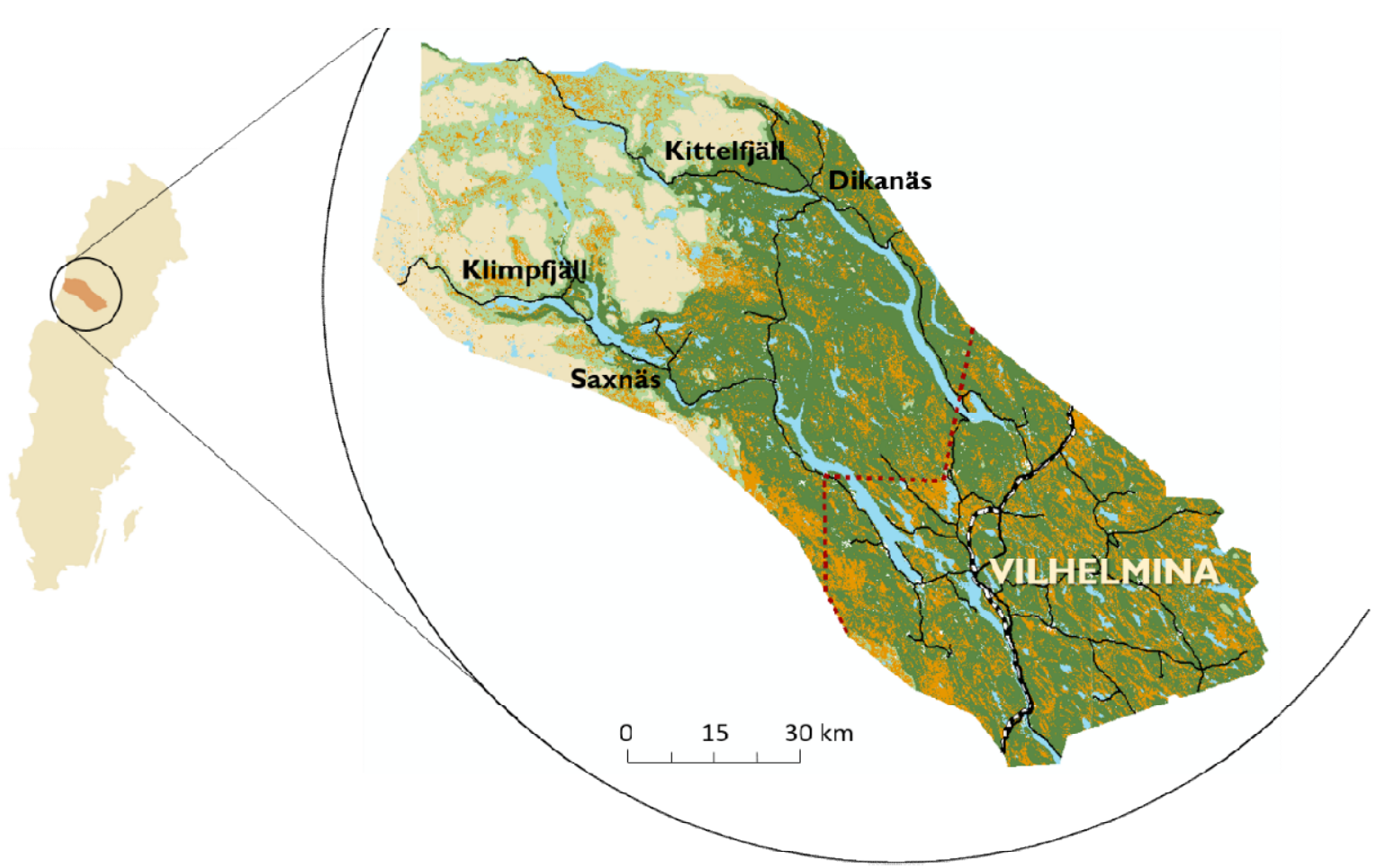

Figure 1: The location of the Vilhelmina municipality and Vilhelmina Model Forest in Sweden, indicating the largest villages, roads and railway and the distribution of land cover classes: Dark green - forest; yellow - mires and agricultural land; blue - water; light green - mountain birch tree-line forest; white - high alpine without woody vegetation. Map made by Camilla Thellbro.

\subsection{Semi-structured interviews}

We conducted qualitative interviews, in total 32 face-to-face interviews, to create an empirical basis of local forest stakeholder perspectives. The interviews were semi-structured with openended questions that followed Kvale (1996). The participants were both men and women, resident and non-resident stakeholders, and of varying age. The following interest categories were represented: NIPF owners or forest owner organisations (22 people); forestry industry and entrepreneurs (4); national, county level or local authorities (6); nongovernmental organisations (nature conservation, game management, geology, Sami people) (5); and one person representing education and research. Some participants represented more than one category, and all participants also had an interest in various outdoor recreation. The participants were contacted with help of the local Swedish Forest Agency office and the VMF network (Vilhelmina Model Forest 2016).

The interview questions aimed to capture the stakeholder participants' understanding of the role of forest values in the landscape, ownership rights, forest policy and management premises, and actor networks and collaboration, focusing on governance challenges from a NIPF ownership perspective. The duration of the interviews was around 90 minutes (60 to 120 minutes). All interviews were recorded and transcribed. The transcripts were analysed and coded following grounded theory (Charmaz 2006). The codes were grouped into four broad thematic areas:

1) Ownership and forest landscape values;

2) Forest policy and management premises;

3) Sectorial planning tradition;

4) Collaboration and the need of a landscape perspective (see also Table 1).

The original interview language was Swedish, so all of the interview excerpts presented here are the authors' translations into English. Confidentiality was maintained throughout, which is why no references to the representation are made after the quotes, as the interview persons would then be easy to identify. 


\subsection{Analytical framework}

By departing from identified obstacles in collaborative planning literature (e.g. Healey 1997; Innes 2016; Margerum 2011), we created an analytical framework that was operationalised in a Swedish municipal context to examine the possibilities for using a collaborative landscape approach (Opdam et al. 2015). Following Margerum (2002) as one illustrative and practically oriented example, we perceived collaborative planning as an interactive process of consensus building and implementation using stakeholder and public involvement. However, the practical implementation of collaborative planning often confronts a range of significant obstacles involving compositional, contextual, operational, organisational and ideological aspects, as well as power and capacity (Margerum 2002). In this study we addressed all of these aspects. The compositional aspect refers to the degree of stakeholder inclusiveness; the ideological aspect may be obstacles in terms of differing perceptions of problems; and contextual considers for example societal-level dynamics, technical complexity and historical obstacles. The operational aspect refers to availability of adequate resources (financial, knowledge, time etc.) as well as to the facilitation of the process (for example a trained facilitator, consensus among stakeholders). The organisational aspect concerns factors such as political and organisational cultures and organisational disincentives. Lastly, the aspect of power and capacity refers to the capacity to manage, influence and understand processes and mobilise for action, and consequently reflects that stakeholders have such skills and are able to use them with trustworthiness and respect.

Along the lines of Margerum (2002) but more applied, Andersson et al. (2013) identified three main problems regarding the implementation of collaborative approaches on the municipality level in Sweden:

(1) the lack of skills in developing collaboration;

(2) a lack of initiative that integrates relevant stakeholders to address sustainability issues; and

(3) a lack of information on status and trends for sustainability that cover entire landscapes available to stakeholders.

We complemented the theoretical categorisation of obstacles identified by Margerum (2002) with the problems in a Swedish municipal context identified by Andersson et al. (2013) to create a framework for assessing theoretical and empirical findings reported in the literature in the context of local stakeholder perspectives in Vilhelmina. Where Margerum's practice-oriented model operationalise organisational challenges on a general level, Andersson exemplify technical problems in development of collaboration. The grouping and correspondence of barriers between Margerum (2002) and Andersson et al. (2013) could be done in several ways, where we chose, in our opinion, the most clear connection to create an illustrative example (see Table 2), even though the barriers interact with each other.

\section{Local views on integrated landscape planning}

The NIPF owners are according to tradition and policy expected to consider multiple values and services in their management and other land-use on their land to satisfy both private individual and public goals - e.g., biodiversity, reindeer husbandry, recreation, tourism, hunting, water management, etc. This has resulted in a complex governance situation when considering the strong ownership rights tradition in Sweden. The ownership rights are regarded as crucial in "development, welfare and natural resource management, being deeply rooted in history, identity and local practice" (Ambjörnsson et al. 2016, p. 114). This matter is strongly reflected among the interview persons, who shared and represented several views on forest ownership objectives. Different typologies of forest owners can be found in the literature (Ficko et al. 2017). In this explorative study we were able to distinguish three types of views on ownership rights and forest management goals among our interviewees, at large corresponding with the forest owner typologies by Ingemarson et al. (2006), Nijnik\& Mather (2008) and 
Wiersum et al. (2005) ${ }^{2}$. First, the economist type, who regards the main forest goal as the production of saw logs and pulp wood for economic revenue. This group of forest stakeholders (14 interviewees) holds strongly on the fundaments of ownership rights and guard their exclusive "self-evident" right to determine the use of their forest property themselves (Table 1:1).

Second, the multi-objective type, promotes the timber production objectives and the importance of well-managed forests, but also acknowledges the demands of diverse high-quality values and products to meet market demands (Table 1:2 a-c). Interviewees advocating this view (11) displays insight in the need of a landscape perspective and multifunctionality. They support further development of multifunctional forestry serving several objectives by using natural variation and multiple tree species, protecting biodiversity, securing water quality, and promoting recreation values for leisure and hunting, etc. in the landscape. They see new business production sectors as alternatives to traditional saw logs and pulpwood products. For example, there is a pronounced interest in expanding nature tourism and negotiating contracts with specific forest usersgroups for financial remuneration of the products and services provided.

Third, the conservationist type, expressed by three interviewees, focuses on the intrinsic value of nature as a common; maintaining and creating new areas of wilderness and ecosystem goods and services (Table 1:3 a-b).

Many of the interview participants described a strong public opinion and attachment to the forest resource in general. They all spend time in the forests pursuing leisure and recreational activities, hunting and fishing, etc. The willingness of NIPF owners to make considerations to multiple interests is a key issue regarding present constraints for implementing a landscape approach in forest planning. At the same time, the ownership rights are strongly acknowledged. In the interviews, the

2 Some interview persons could be connected to several views, foremost both 2 and 3 , but were added to the most pronounced one, and four of the stakeholders were not possible to categorise. most frequent examples of what is experienced as intrusions on ownership rights are nature reserve establishments and registration of woodland key habitats $^{3}$ in forest areas planned to be harvested, access for tourism or berry enterprises, adaptations to reindeer husbandry demands, and limitations in the use of continuous cover forest management ${ }^{4}$. NIPF owners often question their responsibility on behalf of other interests since they own the land, pay for the management, pay taxes and so forth. Several participants argued that the 'freedom with responsibility' results in a diversified forest management that meets several interests, but questioned whether it is possible to meet all the interests with financial means and if it is possible to determine an acceptable level of consideration and its costs (Table 1:4 a-b).

Several interviewees noted that political institutions and opinions have a large mandate to decide on the future forest management, but also that consumers, market prices, and not least the large-scale forest companies, as dominant players in the forest sector, are important drivers in decision making. Others argued that the market influence exceeds the political means (Table 1:4 c).

Furthermore, the interviewees expressed that decision-making is taking place too far away from the local area. There is a general feeling that it is difficult to influence political decision making, since that requires lobbying on a higher political level. In addition, many decisions have an indirect effect on forestry; e.g., concerning infrastructure, tax levels, and employer fees (Table 1:4 d).

Regarding the sectorial planning tradition, some of the interviewees raised critiques about the streamlined policy and management paradigm (Table 1:5 a). In addition to the sectorial planning tradition, the need to shift focus from estate levels to a landscape level and multifunctional perspective, was also expressed (Table 1:5 b).

3 Notification, but without formal protection status, of a demarcated area as a habitat with high nature conservation values; see e.g. Gustafsson et al. (1999).

4 use of silvicultural systems whereby the forest canopy is maintained at one or more levels without clear felling. 
Concerning collaboration and the need of a landscape planning approach, the challenges of sectorial planning and the diverse views on the objectives of forest management was highlighted through arguments for collaborative, participatory and knowledge and information exchange, as examples of governance means for securing rural development. Apparently, their association with
VMF as a potential forum and arena has generated positive prospects for increased local consensusmaking and democracy (Table 1:6 a-c). However, there is also critique raised towards how the VMF has succeeded so far, highlighting a common challenge of participatory processes, namely the incentives for engaging voluntarily in demanding and time consuming meetings (Table 1:6 d).

Table 1: Example of statements in the interviews. The quotes are sorted by the thematic codes and are referred to in text by the numbers in the second column (first theme has three numbers for each owner type). The quotes are connected to potential solutions as to how improve ILP through (broker, arena and/or tool) in the end right column.

\begin{tabular}{|c|c|c|}
\hline Themes & No & Quotes from interviews \\
\hline \multirow{6}{*}{$\begin{array}{l}\text { Ownership } \\
\text { and forest } \\
\text { landscape } \\
\text { values }\end{array}$} & 1 & $\begin{array}{l}\text { The economic interest is the largest, regardless of whether you } \\
\text { are a large-scale or small-scale forest owner. }\end{array}$ \\
\hline & $2 a$ & $\begin{array}{l}\text { We must look broadly at forestry; that is the key. An area can } \\
\text { vary so much. It fosters multiple uses of the land, to maximise its } \\
\text { utility. Then, it is the economy of the owner that rules. }\end{array}$ \\
\hline & $2 b$ & $\begin{array}{l}\text { I want to perform highly active forestry and use the potential of } \\
\text { all kinds of values - timber production, tourism values, nature } \\
\text { values, recreation. }\end{array}$ \\
\hline & $2 c$ & $\begin{array}{l}\text { There seems to be a larger openness to variation in management. } \\
\text { People think forward - how do I want to manage my estate, what } \\
\text { values to produce, use alternative cutting methods, consider } \\
\text { climate change adaptation. }\end{array}$ \\
\hline & $3 a$ & $\begin{array}{l}\text { If I happen to own a piece of land, then I have almost unlimited } \\
\text { possibilities to do what I want. I have a hard time accepting that. } \\
\text { In a society, everyone is dependent on the land and on the } \\
\text { climate and environment. }\end{array}$ \\
\hline & $3 b$ & $\begin{array}{l}\text { I think it is very good to make reserves, very good indeed. It is not } \\
\text { reasonable that I should be able to harvest all. I am very happy } \\
\text { that one has limited that kind of forestry. /... I I want to } \\
\text { contribute to the protection of unique nature. But as we protect } \\
\text { it for the benefit of all, it is not reasonable that I should bear the } \\
\text { costs alone. }\end{array}$ \\
\hline
\end{tabular}

Solution

Broker

Broker, Tool

Tool, Arena Tool

Broker

Broker, Arena, Tool
Broker Arena, Tool 
What does the tourism industry pay to me as a forest owner? Where did the ownership rights go? We should maintain the Public Rights of Access, but there are customs for what is allowed.

$4 \mathrm{~b}$ As kids we joined the reindeer separation, it [reindeer Broker, husbandry] was closely related and we had a lot to do with them, Arena but today I feel injustice from an entrepreneur perspective. I have to pay consideration to their enterprise in my forest management, but their enterprise does not need to consider mine. It is important to look at it from both perspectives. We have to reach consensus.

$4 \mathrm{c}$ One can surely find and develop new conservation strategies that allow us to still use the land. It could be possible to conduct a Broker, careful selective cutting in a nature reserve, making it possible to Arena take out high-quality timber, to make it economically sustainable.

$4 \mathrm{~d}$ Those with power are not here, neither for reindeer husbandry, Broker, forestry nor nature protection. Not even on the municipality Arena level. The real power is to be found at the state level through directives, etc.

\begin{tabular}{|c|c|c|c|}
\hline \multirow[t]{2}{*}{$\begin{array}{l}\text { Sectorial } \\
\text { planning } \\
\text { tradition }\end{array}$} & $5 \mathrm{a}$ & $\begin{array}{l}\text { Within the near future, in one or two decades, I think the main } \\
\text { actors will remain to be the forest companies, which do almost } \\
\text { whatever they want. The authority will "walk in their leash". They } \\
\text { will think in the same way, production and rationality, the } \\
\text { economic aspect superior of all other values. }\end{array}$ & $\begin{array}{l}\text { Broker, } \\
\text { Arena, } \\
\text { Tool }\end{array}$ \\
\hline & $5 b$ & $\begin{array}{l}\text { As regards final felling, there must be a certain responsibility to } \\
\text { put a holistic view on the landscape, across estate borders. If } \\
\text { several land owners clear-cut at the same time, large areas are } \\
\text { impacted overall. One has to consider that. There are many } \\
\text { values to handle; high nature values, cultural heritage, reindeer } \\
\text { husbandry, social values. What is missing in general is the } \\
\text { landscape perspective. It is difficult, even at the forest agency, } \\
\text { even though it is demanded in documents by both managers and } \\
\text { politicians. Just defining what a landscape is... [is challenging]. }\end{array}$ & $\begin{array}{l}\text { Broker, } \\
\text { Arena, } \\
\text { Tool }\end{array}$ \\
\hline
\end{tabular}

Collaborati- $6 \mathrm{a}$ It all concerns how to use the common nature resource. If we Arena on and the could come closer to the core values through VMF, it would need of a landscape enable large changes in the local community and lift the issue to another level; to have the courage to problematise and focus on perspective the importance for future survival. To build and develop a stronger local society while at the same time as preserving and maintaining values - that's where the MF can contribute. 
$6 \mathrm{~b} \quad$ But in the long term one could hope that there are those working Arena to establish another kind of decision-making with more involvement of other forest and land stakeholders, where the social and cultural, and not least the ecological values are incorporated. One could hope that, in the long term, a more deepened participation based forest management will develop. It is not only the forest owner who should decide what he wants. The MF has this ambition; it is reasonable in all sorts of ways.

$6 \mathrm{c}$ A problem is that people have too little knowledge, that they do not understand each other's interests. In VMF people are beginning to talk and understand, see visions; I believe in that.

$6 \mathrm{~d}$ I think it is a failure that so few people know what VMF is. It was supposed to be something so interesting that people would like to engage and contribute, based on voluntarism. However, people do not have the energy, time or resources to engage, especially if you cannot make it economically feasible for land owners.

\section{Opportunities for integrated landscape planning}

The empirical material has contextualised the institutional conditions in Sweden in general, and Vilhelmina in particular. Based on the interviews, we discuss three potential solutions that correspond to the obstacles and problems regarding the implementation of integrated landscape planning (ILP) identified and exemplified by Margerum (2002) and Andersson et al. (2013); these are summarised as barriers for ILP in Table 2.

Departing from Andersson et al. (2013), the key questions are: how to develop facilitation and leadership skills for enabling collaboration; how to stimulate knowledge and information exchange; and how to assist stakeholder initiated arenas where an integrated landscape planning can be nourished. The interview study revealed constraints imposed by sectorial planning, the ability of local forest stakeholders in Vilhelmina to consider the wider forest landscape, and highlighted the potential for Model Forests to act as arenas for collaborative stakeholder engagement. Below we suggest and present three opportunities for making forest planning more collaborative and inclusive of multiple landscape values.

\subsection{The broker - neutral coordination and mediation}

There is a need for legislative changes to foster the implementation and training of collaborative techniques (Carr et al. 1998). Effective involvement of forest stakeholders requires institutionalised participation on all levels of governance, from policy formulation to local-level planning (Raitio 2012). Clear administrative responsibilities and more harmonised policies between pan-national, national, regional (county) and local (municipality) levels are needed in order to make the governance situation transparent and efficient in landscape management and planning (Svensson et al. 2012).

Working infrastructure and communication routines to inform land-use actors need to be established in order to ensure collaboration and understandable outcomes (Boon 2000; Innes \& Booher 2010; Wondolleck \& Yaffee 2000), as well as coordinated and comprehensive information about ongoing 
Table 2: Departing from the institutional conditions, this table illustrate how we synthesise the barriers for ILP from obstacles and problems described in the analytical framework, and from highlighted challenges in the interviews. To overcome those barriers, we suggest three thematic solutions.

\begin{tabular}{|c|c|c|c|}
\hline \multicolumn{4}{|c|}{$\begin{array}{l}\text { Institutional conditions } \\
\text { Forest ownership structure; Sectorial planning tradition; Forest policy and management premises }\end{array}$} \\
\hline \multicolumn{3}{|c|}{ Barriers for ILP } & Opportunities for ILP \\
\hline \multicolumn{2}{|c|}{$\begin{array}{l}\text { Analytical framework } \\
\text { Margerum (2002) } \\
\text { Andersson et al. (2013) }\end{array}$} & Interviews & Solutions \\
\hline $\begin{array}{l}\text { Power and } \\
\text { capacity }\end{array}$ & $\begin{array}{l}\text { Lack of skills } \\
\text { to develop } \\
\text { collaboration }\end{array}$ & $\begin{array}{l}\text { - Lack of landscape-level } \\
\text { governance and } \\
\text { administration } \\
\text { - Lack of communication } \\
\text { between sectors and } \\
\text { stakeholders } \\
\text { - Different views on ownership } \\
\text { rights }\end{array}$ & $\begin{array}{l}\text { Landscape Coordinator } \\
\text { "The broker" }\end{array}$ \\
\hline Organisational & \multirow{2}{*}{$\begin{array}{l}\text { Lack of initiative } \\
\quad \text { /arena }\end{array}$} & \multirow{2}{*}{$\begin{array}{l}\text { - Varying possibilities and } \\
\text { resources to take part in } \\
\text { collaborative processes } \\
\text { - Lack of communication and } \\
\text { knowledge exchange }\end{array}$} & \multirow{2}{*}{$\begin{array}{l}\text { Vilhelmina Model Forest } \\
\text { "The arena" }\end{array}$} \\
\hline Compositional & & & \\
\hline Contextual & \multirow{2}{*}{$\begin{array}{c}\text { Lack of } \\
\text { information }\end{array}$} & $\begin{array}{l}\text { - No coordination between } \\
\text { neighbouring estates } \\
\text { - No coordinated overview or } \\
\text { consequence analysis of } \\
\text { multifunctional values on }\end{array}$ & \multirow{2}{*}{$\begin{array}{l}\text { Enhanced forest } \\
\text { management plan } \\
\text { "The tool" }\end{array}$} \\
\hline Ideological & & $\begin{array}{l}\text { - Short planning horizon (10- } \\
20 \text { years) } \\
\text { - Lack of consideration of } \\
\text { social values }\end{array}$ & \\
\hline
\end{tabular}

planning processes, decisions and consequences for the stakeholders and the natural values in forest landscapes. Such transparency is a prerequisite for effective collaboration among different societal sectors and levels of governance (Adger \& Jordan 2009; Borrini-Feyerabend 2004).

The European Landscape Convention states that protection, management and planning of landscapes are most effective if responsibility is entrusted to the competent authorities closest to the communities concerned (Jones \& Stenseke 2011). Andersson et al. (2013) also pointed out that functional collaboration requires the competence of communicators or facilitators in order to develop a successful process. The implementation of participatory approaches is a challenge, especially as it may be unclear how administrations should adopt multi-purpose 
planning, inter-sectoral coordination and manage conflict resolution (Böhling \& Arzberger 2014). In situations where collaborative processes involve negotiations for what could be uncertain goals and outcomes, there is a need to institutionalise stakeholder participation and create organisational cultures that can facilitate such processes (Reed 2008).

One suggestion that has been raised in the VMF (Jougda, former VMF general manager, 2015, personal communication), is the concept of a 'landscape coordinator' (landskapslots in Swedish). The landscape coordinator should act as a broker and pilot to guide, mediate and close the gap between decision makers and those that are affected by decisions, as well as assist in 'interpreting' scientific knowledge and legislative policies into practical advices. This suggestion of a broker corresponds with arguments brought forward in similar concepts, such as the landscape node (Esselin 2014), the landscape connoisseur (Arler \& Mellqvist 2015), the landscape representative (Hammer \& Siegrist 2016) and the demand for strong leadership in collaborative processes and planning (Bjärstig \& Kvastegård 2016; Emerson et al. 2012). Albert \& Vargas-Moreno (2011) argued for how such an "expert-facilitator" role could mediate and advise in the complex debate of land resource planning between multiple actors. The broker will contribute to improved consultations between different actors who are using the landscape and advocate the landscape perspective in different decision-making processes. By having a coordinated and holistic view, and ensuring that relevant stakeholders and areas of interests are included, local and regional collaboration will be strengthened. The broker should act as a neutral third party and arrange meetings, initiate dialogues and chair various processes to build confidence and trust among involved stakeholders as well as securing quality evaluation and monitoring of the processes. In accordance with Margerum (2002), this broker will have the operational capacity to handle the process and give all stakeholders some influence, regardless of their formal power. To foster resilience and decrease vulnerability, the landscape coordinator could be a group of people rather than relying on one single person's responsibility and presence.

\subsection{The arena - a landscape case study for collaboration, testing and demonstrating}

As Svensson et al. (2012), among others, have argued, there is a need to develop better strategies and tools that are able to balance multiple interests, and to improve infrastructure and communication routines between land use actors, decision makers and the public in Sweden (see also Bjärstig \& Sandström 2017). There is a clear need for networks that connect horizontal and vertical links between different partners, actors and stakeholders (Berkes et al. 1998; Elbakidze et al. 2010). Integration within and across sectors is required in order to deliver an increased pool and diversity of landscape values (Angelstam etal. 2015). Mora etal. (2013) argued that a landscape approach requires local fora for aligning ecosystem goods and services, territorial dynamics and sectorial relationships. In order to incorporate landscape planning in practice, increased knowledge sharing and interaction between actors must take place, accompanied by improved consultation processes and tools to handle the administrative, political and governance challenges.

A number of cases or concepts have been initiated in Sweden and elsewhere to promote a landscape approach fostered by participation and dialogue. Examples include the EU Leader programme (Ray 2000; Swedish Board of Agriculture 2016), the Natura 2000 (SEPA 2016), the Biosphere Reserve (Richnau et al. 2013), the river catchment-based planning within the European Water Framework Directive (Hammer et al. 2011; Lundmark \& Jonsson 2014), and the Model Forest initiative (Bonnell et al. 2012; Ho et al. 2014). Most of those landscape approaches aim to reach sustainable resource management and development of social capital, democracy and dialogue (Esselin 2014). One example that has been brought forward in VMF to facilitate understanding between different actors and forest management is demonstration areas and hiking trails where relevant information is displayed for the public. Esselin (2014) also stressed the importance of increasing the exchange of experiences between the above mentioned landscape initiatives.

The diversity of opinions among the public and other 
stakeholders in sustainable use and management of the natural capital should be seen as a resource for creating new ideas and prospects. However, further exploration is required of what benefits and outcomes that can be generated in a collaborative planning process. One way would be to further explore the possibilities to develop and work with the Model Forest-concept. The purpose of a Model Forest is to foster sustainability and reflect the values, needs and management and governance challenges of stakeholders in the local community through knowledge sharing and transparent governance (Ho et al. 2014). During its time of existence, the VMF has generated a network that is able to connect people, stakeholders, research projects, international exchanges and demonstration examples. Following Margerum (2002), there are organisational aspects of e.g. power, inclusiveness, and influence, that work in favour of a collaborative planning process. According to our understanding, VMF holds potential in this respect as a forum for different actors to discuss conflicting views and interests, with the aim of achieving high-quality participatory processes in the future.

\subsection{The planning tool-developedforest management plans}

We argue that the forest management plan (FMP) can be developed in several ways to become a tool for enabling a multifunctional landscape perspective in forest planning and supporting collaborative processes. We argue that there is a good chance that this can be achieved by employing and building on the existing FMP system, which is established in policy and is well known to NIPF owners, forest practitioners and other forest stakeholders (Beland Lindahl et al. 2017). Even though the FMP capacity to include forest social values is undeveloped, we foresee that it should be possible to build on the stand-level classification on production and biodiversity consideration (Angelstam \& Andersson 2001) for a coherent and holistic mapping of economic, ecological and socio-cultural forest values. The current FMP can be criticised for being rather short-sighted without making any consequence analysis of how management activities on one estate influence neighbouring areas or the landscape as a whole (Angelstam et al. 2015). However, by including a consequence analysis on how different forest management activities may influence diverse landscape values, as well as how these values in turn influence the objectives of the NIPF, the FMP may have the potential to advance into a more comprehensive planning tool. The detailed description of an estate that is included in the FMP could be complemented with a description of the surrounding land and how different parts of land and management activities interact with each other to put the estate in a landscape context. It would be relevant in such work to consider landscape character analysis tools (Brabyn 2009; Butler \& Akerskog, 2014; Jellema et al. 2009). Conditions of the diverse ownership behaviour express that planning should be complemented and strengthened by reaching across ownership borders and embracing a landscape planning perspective (Forsberg 2012).

The interviewees emphasised respect for ownership rights. It is important to underline that the forest management decision rights belong to the owner and that any management suggestions made beyond the estate borders have no legal support. However, by extending outwards into surrounding land, if only as an idea, a catalogue of prospects can be created for future advice and opportunities.

In order to make this kind of collaborative and multifunctional forest planning feasible, it is crucial that forest policy makers find a way to organise consultancy, agreements and compensation routines between stakeholders. This argument is supported by Widman \& Bjärstig (2017), who have studied public-private partnerships in the form of voluntary Nature Conservation Agreements (NCAs) regarding forests with high recreational values, as an example of agreements between authorities and NIPF owners where the ownership rights are not interfered with.

The Heureka forest planning system (Wikström et al. 2011) is a potentially powerful tool for integrated analysis of forest management on multiple estates. Heureka is currently being used by all large forest companies in Sweden, as well as a number of NIPF owners with estates of varying size (Heureka 2016) for long-term planning of timber production but 
also for ecological landscape planning. This points at an opportunity for integrated landscape planning involving multiple stakeholders and multifunctional values. For instance, Heureka could be used to analyse the consequences of managing a landscape as one entity rather than as separate forest estate entities. This would elucidate the benefits and costs for each NIPF owner as well as the potential advantages of a common and coordinated strategy for, e.g., nature conservation (Hoen et al. 2006); The output of various types of forest ecosystem values and functions over time can be forecasted in Heureka. Another advantage of using Heureka to create separate as well as aset of combined FMPs is the capability of the system to generate longterm plans for 50-100-year time horizons that still consider the potentially shorter time horizon that is of interest to the forest owner. The time horizon of current FMPs is $10-15$ years, which is rather short from a landscape perspective. In this way, using Heureka to create and analyse FMPs could help forest owners, policy makers and stakeholders to understand what ecosystem services the forest can produce under different circumstances and the consequences of various management strategies. This would provide a base for knowledge and information sharing that can promote constructive dialogue between NIPF owners and with other stakeholders and support decision making. Referring to Margerum's (2002) identified ideological and contextual obstacles, the use and development of FMP as a communicative tool, as well as a planning tool, can help overcome differing perceptions of problems among stakeholders, while Heureka can display societal-level dynamics, technical complexity and historical barriers, and in so doing facilitate ILP in the future.

\section{Concluding remarks}

Identifying obstacles and problems as those reported by Margerum (2002) and Andersson et al. (2013) proved to be a useful approach for this explorative study. By addressing the barriers to ILP in a Swedish context, we have been able to show how collaborative planning and a landscape perspective are crucial for developing sustainable forest management plans into the future.

As international fora and conventions emphasise sustainable development and increased collaboration concerning land use issues and among forest stakeholders and local citizens, the cross-sectorial governance of landscape planning and forest management needs to be raised on the political agenda, both nationally and internationally. There is an evident need to elaborate on collaborative governance methods to handle the complexity of forest values and stakeholders as well as to incorporate a landscape perspective in planning. In line with this we have put forward a solution consisting of three components - the broker, the arena and the tool - that we believe have the potential to help fortify ILP if adopted. We suggest the need for a landscape broker to facilitate collaboration processes between stakeholders, preferably through something like the Model Forest arena; an arena that is already established in Vilhelmina but lacks clear leadership and facilitator positions. We also see potential in developing the FMP into a multifunctional landscape planning tool, which can enhance the collaborative dimension by leveraging different perspectives and stakes among the involved stakeholders.

For future research, we conclude that it is important to develop common definitions, tools and measurements for ILP and to investigate how to handle trade-offs between values and interests in the landscape. Well-functioning collaborative conditions and willingness for dialogue needs to be further examined and tested in other local, political and administrative systems. More concrete descriptions and detailed steps in the development of the three components needs to be investigated 
further, depending on the local context. Overall however, the broker, the arena and the tool, when treated together as complementary and interacting opportunities, provide prospects and capacity for integrated landscape planning.

\section{Acknowledgement}

This research has received funding from the European Union's Seventh Program for research, technological development and demonstration under grant agreement No. 282887. We warmly thank the interview persons for sharing their valuable time and experiences. We also express our sincere gratitude to the two anonymous reviewers, whose comments greatly helped to improve this paper.

\section{References}

Adger, W. \& Jordan, A. 2009. Governing sustainability. Cambridge University Press, Cambridge - New York.

Albert, C. \& Vargas-Moreno, C. 2011. Planning-Based Approaches for Supporting Sustainable Landscape Development. Landscape Online 19, 1-9.

Ambjörnsson, E. L.; Keskitalo, E. C. H. \& Karlsson, S. 2016. Forest discourses and the role of planningrelated perspectives: the case of Sweden. Scandinavian Journal of Forest Research 31(1), 111- 118.

Andersson, K.; Angelstam, P.; Axelsson, R.; Elbakidze, M. \& Törnblom, J. 2013. Connecting Municipal and Regional Level Planning: Analysis and Visualization of Sustainability Indicators in Bergslagen, Sweden. European Planning Studies 21, 1210-1234.
Angelstam, P.; Andersson, K.; Axelsson, R.; Degerman, E.; Elbakidze, M.; Sjolander, P. \& Tornblom, J. 2015. Barriers and bridges for sustainable forest management: the role of landscape history in Swedish Bergslagen. in: Kirby, K.J. \& C. Watkins C. (Eds.), Changing Woods and Forests. From Wildwood to Managed Landscapes. CABI, Wallingford, p. 290.

Angelstam, P. \& Andersson, L. 2001. Estimates of the Needs for Forest Reserves in Sweden. Scandinavian Journal of Forest Research 16, 3851.

Appelstrand, M. 2012. Developments in Swedish forest policy and administration - from a "policy of restriction" toward a "policy of cooperation." Scandinavian Journal of Forest Research 27, 186199.

Appelstrand, M. 2002. Participation and societal values: the challenge for lawmakers and policy practitioners. For. Policy Econ., National Forest Programmes in a European Context: Findings from COST Action E19 4, 281-290.

Arler, F. \& Mellqvist, H. 2015. Landscape Democracy, Three Sets of Values, and the Connoisseur Method. Environmental Values 24, 271-298.

Beland Lindahl, K.; Sténs, A.; Sandström, C.; Johansson, J.; Lidskog, R.; Ranius, T. \& Roberge, J.-M. 2017. The Swedish forestry model: More of everything? Forest Policy and Economics 77, 4455

Berkes, F.; Folke, C. \& Colding, J. 1998. Linking social and ecological systems: management practices and social mechanisms for building resilience. Cambridge University Press, Cambridge.

Berlan-Darqué, M.; Luginbühl, Y. \& Terrasson, D. 2008. Landscape, from Knowledge to Action. Editions Quae. 
Bettinger, P.; Boston, K.; Siry, J.P. \& Grebner,D.L. 2009. Forest management and planning. Academic, Amsterdam - London.

Bjärstig, T. \& Kvastegård, E. 2016. Forest social values in a Swedish rural context: The private forest owners' perspective. Forest Policy and Economics $65,17-24$.

Bjärstig, T.; Thellbro, C.; Stjernström, O.; Svensson, J.; Sandström, C.; Sandström, P. \& Zachrisson, A. 2017. Between protocol and reality-Swedish municipal comprehensive planning. European Planning Studies, 1-20.

Bjärstig, T. \& Sandström, C. 2017. Public-private partnerships in a Swedish rural context. Journal of Rural Studies 49.

Böhling, K. \& Arzberger, M.B. 2014. New modes of governance in Bavaria's alpine forests: The "Mountain Forest Initiative" at work. Forest Policy and Economics 49, 43-50.

Bolliger, J.; Bättig, M.; Gallati, J.; Kläy, A., Stauffacher, M. \& Kienast, F. 2010. Landscape multifunctionality: a powerful concept to identify effects of environmental change. Regional Environmental Change 11, 203-206.

Bonnell, B.; de Camino, R.; Diaw, C.; Johnston, M.; Majewski, P.; Montejo, I.; Segur, M. \& Svensson, J. 2012. From Rio to Rwanda: Impacts of the IMFN over the past 20 years. Forestry Chronicle 88, 245-253.

Boon, T.E. 2000. Conceptualisation and evaluation of public participation in Danish state forest management (Ph.D.-Dissertation). Royal Veterinary and Agricultural University, Danish Forest and Landscape Research Institute.

Borrini-Feyerabend, G. 2004. Sharing power: learning by doing in co-management of natural resources throughout the world. IIED and IUCN/ CEESP/ CMWG, Cenesta - Tehran.
Brabyn, L. 2009. Classifying Landscape Character. . Landscape Research 34, 299-321.

Brandt, J. \& Vejre, H. 2004. Multifunctional landscapes. Vol. 1, Theory, values and history, Advances in ecological sciences, 1369-8273; 14. WIT Press, Southampton.

Brukas, V. \& Sallnäs, O. 2012. Forest management plan as a policy instrument: Carrot, stick or sermon? Land Use Policy 29, 605-613.

Bush, T. 2010. Biodiversity and Sectoral Responsibility in the Development of Swedish Forestry Policy, 1988-1993. Scandinavian Journal of History, 35(4), 471-498.

Butler, A. \& Akerskog, A. 2014. Awareness-raising of landscape in practice. An analysis of Landscape Character Assessments in England. Land Use Policy 36, 441-449.

Carr, D.S.; Selin, S.W. \& Schuett, M.A. 1998. Managing public forests: Understanding the role of collaborative planning. Environmental Management 22, 767-776.

Carvalho-Ribeiro, S.M.; Lovett, A. \& O'Riordan, T. 2010. Multifunctional forest management in Northern Portugal: Moving from scenarios to governance for sustainable development. Land Use Policy 27, 1111-1122.

Charmaz, K. 2006. Constructing grounded theory: a practical guide through qualitative analysis, Introducing qualitative methods. London - SAGE.

Cullotta, S.; Bončina, A.; Carvalho-Ribeiro, S.M.; Chauvin, C.; Farcy, C.; Kurttila, M. \& Maetzke, F.G. 2015. Forest planning across Europe: the spatial scale, tools, and inter-sectoral integration in landuse planning. Journal of Environmental Planning and Management 58, 1384-1411. 
de Groot, R. 2006. Function-analysis and valuation as a tool to assess land use conflicts in planning for sustainable, multifunctional landscapes. Landsc. Urban Plan., Landscapes and sustainability 75, 175-186.

Dolman, P.M.; Lovett, A.; O’Riordan, T. \& Cobb, D. 2001. Designing Whole Landscapes. Landsc. Res. 26, 305-335.

Emerson, K.; Nabatchi, T. \& Balogh, S. 2012. An Integrative Framework for Collaborative Governance, Journal of Public Administration Research and Theory, Volume 22, Issue 1, 1 January 2012, 1-29.

Elbakidze, M.; Angelstam, P.K.; Sandström, C. \& Axelsson, R. 2010. Multi-stakeholder collaboration in Russian and Swedish model forest initiatives: adaptive governance toward sustainable forest management? Ecology \& Society 15.

Esselin, A. 2014. Landskapsnoden - Förutsättningar. Kungliga skogs- och lantbruksakademien (KSLA), Stockholm.

FAO 2016. State of the world's forests 2016. Forests and agriculture: land-use challenges and opportunities. FAO, Rome.

Farcy, C. 2004. Forest Planning in Europe: State of the Art, International Debates, Emergent Tools. In: Andersson, F., Birot, Y., \& Päivinen, R. (Eds) In Towards the Sustainable Use of Europe's ForestsForest Ecosystem and Landscape Research: Scientific Challenges and Opportunities, 11-20. Joensuu: European Forest Institute.

Ficko, A.; Lidestav, G.; Dhubháin, Á.N.; Karppinen, H.; Zivojinovic, I. \& Westin, K. 2017. European private forest owner typologies: A review of methods and use. Forest Policy and Economics. In press.

Forsberg, M. 2012. Skogen som livsmiljö: En rättsvetenskaplig studie om skyddet för biologisk mångfald. Dissertation, Uppsala University.
Gallent, N.; Andersson, J. \& Bianconi, M. 2004. Vision for a Sustainable, Multifunctional Rural-Urban Fringe. Countryside Agency, Cheltenham.

Gustafsson, L.; Jong, J.D. \& Noréng, M. 1999. Evaluation of Swedish woodland key habitats using red-listed bryophytes and lichens. Biodiversity and Conservation 8,1101-1114.

Hahn, W. A. \& Knoke, T. 2010. Sustainable development and sustainable forestry: analogies, differences, and the role of flexibility. European Journal of Forest Research, 129 (5), pp 787-801.

Hammer, M.; Balfors, B.; Mortberg, U.; Petersson, M., \& Quin, A. 2011. Governance of Water Resources in the Phase of Change: A Case Study of the Implementation of the EU Water Framework Directive in Sweden. Ambio 40, 210-220.

Hammer, T. \& Siegrist, D. 2016. Swiss landscape policy form the European Landscape Convention perspective. Chapter 14 in: Jørgensen, K.; Clemetsen, M.; Thorén, K.H. \& T. Richardson (Eds.). Mainstreaming Landscape through the European Landscape Convention. Routledge Abingdon - Oxon- New York.

Healey, P. 1997. Collaborative planning: Shaping places in fragmented societies. UBC Press, Vancouver.

Heureka 2016. Heureka forest planning system webpage. http://www.slu.se/en/CollaborativeCentres-and-Projects/forest-sustainabilityanalysis/heureka/heureka-systemet/en-heureka/ (Date: 12.5.2016)

Ho, V.M.; Bonnell, B.; Kuschalappa, C.; Mooney, G.; Sarasin, J.; Svensson, J. \& Verbinsky, R. 2014. Governance solutions from the International Model Forest Network., in: Towards Sustainable Landscapes, ETFRN News. ETFRN and Tropenbos International, Wageningen, Netherlands, pp. 2634. 
Hoen, H.F.; Eid, T. \& Økseter, P. 2006. Efficiency gains of cooperation between properties under varying target levels of old forest area coverage. Forest Policy and Economics 8, 135-148.

Hokajärvi, R.; Hujala, T.; Leskinen, L.A. \& Tikkanen, J. 2009. Effectiveness of sermon policy instruments: forest management planning practices applying the activity theory approach. Silva Fenn. 43, 889906.

Holmgren, S. \& Arora-Jonsson, S. 2015. The Forest Kingdom - with what values for the world? Climate change and gender equality in a contested forest policy context. Scandinavian Journal of Forest Research 30, 235-245.

Hujala, T.; Kurttila, M.; Tikkanen, J.; Leskinen, P. \& Leskinen, L.A. 2009. Adaptive consultation: a tool for recognizing family forest owners' amenity values. Seeing the Forest Beyond the Trees. IUFRO 3.08 Small Scale Forestry Symposium Proceedings.

Hysing, E. 2009. Statslös samhällsstyrning? Governance i svensk skogspolitik, in: Hedlund, G., Montin, S. (Eds.), Governance På Svenska. Santérus Academic Press Sweden, Stockholm.

IMFN (International Model Forest Network) 2015. http://www.imfn.net (Date: 9.15.2015).

Ingemarson, F. 2004. Small-scale forestry in Sweden: owners' objectives, silvicultural practices and management plans. Swedish University of Agricultural Sciences, Uppsala.

Ingemarson, F.; Lindhagen, A. \& Eriksson, L. 2006. A typology of small-scale private forest owners in Sweden. Scand. J. For. Res. 21, 249-259.

Innes, J. E. 2016. Viewpoint Collaborative rationality for planning practice. Town Planning Review 87:1, 1-4.
Innes, J.E. \& Booher, D.E. 2010. Planning with complexity: an introduction to collaborative rationality for public policy. Routledge, London.

Jellema, A.; Stobbelaar, D.-J.; Groot, J.C.J. \& Rossing, W.A.H. 2009. Landscape character assessment using region growing techniques in geographical information systems. . Journal of Environmental Management 90, S161-S174.

Jones, M. \& Stenseke, M. 2011. The European LandscapeConvention:challenges of participation, Landscape series 13. Springer Verlag, Dordrecht.

Jørgensen, K.; Clemetsen, M.; Thorén, K.H. \& Richardson, T. 2016. Mainstreaming landscape through the European Landscape Convention. Routledge, Abingdon, Oxon - New York.

Keough, H.L. \& Blahna, D.J. 2006. Achieving integrative, collaborative ecosystem management. Conservation and Biology 20, 1373-1382.

Kindstrand, C., Norman, J., Boman, M. \& Mattsson, L. 2008. Attitudes towards various forest functions: A comparison between private forest owners and forest officers. Scandinavian Journal of Forest Research 23, 133-136.

Kvale, S. 1996. Interviews - An introduction to Qualitative Research Interviewing. Sage Publications, Inc., Thousand Oaks, CA.

Lundmark, C. \& Jonsson, G. 2014. Prospects for learning in river management: exploring the initial implementation of the Water Framework Directive in a Swedish river basin. Environmental Education Research 20, 161-176.

MacFarlane, R. 2007. Multifunctional landscapes: conceptual planning issues for the countryside. Chapter 8. In: Benson, J. F. \& Roe, M. H. (Eds) Landscape and sustainability. UK: Routledge, London. 
Margerum, R.D. 2002. Collaborative Planning Building Consensus and Building a Distinct Model for Practice. . Journal of Planning Education and Research 21, 237-253.

Margerum, R.D. 2011. Beyond Consensus: Improving Collaborative Planning and Management. MIT Press.

Mikusinski, G.; Blicharska, M.; Antonson, H.; Henningsson, M.; Goransson, G; Angelstam, P. \& Seiler, A. 2013. Integrating Ecological, Social and Cultural Dimensions in the Implementation of the Landscape Convention. . Landscape Research 38, 384-393.

Monroe, A.S. \& Butler, W.H. 2015. Responding to a policy mandate to collaborate: structuring collaboration in the collaborative forest landscape restoration program. Journal of Environmental Management 0, 1-19.

Mora, O.; Banos, V.; Regolini, M. \& Carnus, J.-M. 2013. Using scenarios for forest adaptation to climate change: a foresight study of the Landes de Gascogne Forest 2050. Annals of Forest Science 71, 313-324.

Nijnik, M. \& Mather, A. (2008). Analyzing public preferences concerning woodland development in rural landscapes in Scotland. Landscape and urban planning, 86(3), 267-275.

Opdam, P.; Coninx, I.; Dewulf, A.; Steingröver, E.; Vos, C. \& van der Wal, M. 2015. Framing ecosystem services: Affecting behaviour of actors in collaborative landscape planning? Land Use Policy 46, 223-231.

Raitio, K. 2012. New institutional approach to collaborative forest planning on public land: Methods for analysis and lessons for policy. Land Use Policy 29, 309-316.
Ray, C. 2000. The EU LEADER programme: Rural development laboratory. Sociologia Ruralis 40, 163.

Reed, M.S. 2008. Stakeholder participation for environmental management: A literature review. Biological Conservation 141, 2417-2431.

Richnau, G.; Angelstam, P.; Valasiuk, S.; Zahvoyska, L.; Axelsson, R.; Elbakidze, M.; Farley, J.; Jönsson, I. \& Soloviy, I. (2013). Multifaceted Value Profiles of Forest Owner Categories in South Sweden: The River Helge å Catchment as a Case Study. AMBIO, 42(2), 188-200.

Roe, M.H. 2007. The social dimensions of sustainability. Chapter 4., in: Benson, J.F., Roe, M.H. (Eds.), Landscape and Sustainability. Routledge, London - New York.

Sandström, C.; Carlsson-Kanyama, A.; Lindahl, K.B.; Sonnek, K.M.; Mossing, A.; Nordin, A.; Nordström, E.-M. \& Räty, R. 2016. Understanding consistencies and gaps between desired forest futures: An analysis of visions from stakeholder groups in Sweden. Ambio 45, 100-108.

Sandström, C. \& Lindkvist, A. 2009. Competing land use associated with Sweden's forests, Future Forest. Umeå, Sweden.

Sandström, C.; Lindkvist, A.; Öhman, K. \& Nordström, E.-M. 2011. Governing Competing Demands for Forest Resources in Sweden. Forests 2, 218-242.

Sandström, P. 2015. A toolbox for co-production of knowledge and improved land use dialogues: the perspective of reindeer husbandry. Swedish University of Agricultural Sciences, Umeå.

Sandström, P.; Cory, N.; Svensson, J.; Hedenås, H.; Jougda, L. \& Borchert, N. 2016. On the decline of ground lichen forests in the Swedish boreal landscape: Implications for reindeer husbandry and sustainable forest management. Ambio 1-15. 
Schlyter, P. \& Stjernquist, I. 2010. Regulatory challenges and forest governance in Sweden, in: Environmental Politics and Deliberative Democracy: Examining the Promise of New Modes of Governance. Edward Elgar, Cheltenham, 180-196.

Secco, L.; Da Re, R.; Pettenella, D.M. \& Gatto, P. 2014. Why and how to measure forest governance at local level: A set of indicators. Forest Policy and Economics 49, 57-71.

Selman, P.H. 2012. Sustainable landscape planning: the reconnection agenda. Routledge, Milton Park - Abingdon - Oxon

SEPA (Swedish Environmental Protection Agency) 2016. Natura 2000. Naturvårdsverket. http:// www.naturvardsverket.se/Stod-i-miljoarbetet/ Vagledningar/Skyddade-omraden/Natura-2000/ (Date: 11.15.2016).

SFA (Swedish Forest Agency) 2014. Swedish statistical yearbook of forestry 2014. Swedish Forest Agency, Jönköping.

SFA (Swedish Forest Agency) 2016. Södra Lappland's disctrict. http://www.skogsstyrelsen.se/Global/ aga-och-bruka/Lokala-sidor/S\%C3\%B6dra\%20 Lappland/S\%C3\%B6dra_Lappland_Statistik.pdf/ (Date: 03.04.2017).

Simonsson, P.; Gustafsson, L. \& Östlund, L. 2015. Retention forestry in Sweden: driving forces, debate and implementation 1968-2003. Scand. J. For. Res. 30, 154-173.

Statistics Sweden 2016. Kommuner i siffror. https:// www.scb.se/hitta-statistik/sverige-i-siffror/ kommuner-i-siffror/\#?region1=2462\&region2=/ (Date: 12.5.2016).

Sténs, A.; Bjärstig, T.; Nordström, E.-M.; Sandström, C.; Fries, C. \& Johansson, J. 2016. In the eye of the stakeholder: The challenges of governing social forest values. Ambio 45, 87-99.
Svensson, J.; Sandstrom, P.; Sandstrom, C.; Jougda, L. \& Baer, K. 2012. Sustainable landscape management in the Vilhelmina Model Forest, Sweden. For. Chron. 88, 291-297.

Swedish Board of Agriculture. 2016. Stöd inom lokalt ledd utveckling - Leader. Jordbruksverket. http:// www.jordbruksverket.se/amnesomraden/stod/st odinomlokaltleddutvecklingleader.4.4dfd5d3a15 26082877c2a853.html (Date: 11.15.2016)

Termorshuizen, J.W. \& Opdam, P. 2009. Landscape services as a bridge between landscape ecology and sustainable development. Landsc. Ecol. 24, 1037-1052.

Vilhelmina Model Forest 2016. http://www. vilhelminamodelforest.se/ (Date: 1.27.2016)

Widman, U. \& Bjärstig, T. 2017. Partnerships potential for protecting forests social values. Scand. J. For. Res. 32(7), 645-656

Wiersum, K.; Elands, B. \& Hoogstra, M. 2005. Small-scale forest ownership across Europe: Characteristics and future potential. Small Scale Forest 4, 1-19.

Wikström, P.; Edenius, L.; Elfving, B.; Eriksson, L.O.; Lämås, T.; Sonesson, J.; Öhman, K.; Wallerman, J.; Waller, C. \& Klintebäck, F. 2011. The Heureka Forestry Decision Support System: An Overview. Math. Comput. For. Nat. Resour. Sci. 3, 87-95.

Wondolleck, J.M. \& Yaffee, S.L. 2000. Making Collaboration Work: Lessons from Innovation in Natural Resource Managment. Island Press. 